\title{
К ВОПРОСУ О СОВЕРШЕНСТВОВАНИИ ОРГАНИЗАЦИИ ГРУЗОПЕРЕВОЗОК СЕЛЬСКОХОЗЯЙСТВЕННОЙ ПРОДУКЦИИ (НА ПРИМЕРЕ ПРЕДПРИЯТИЙ В РАМКАХ АССОЦИАЦИИ «КФХ И АПК СИБИРИ»)
}

\section{P.G. Shvalov, E.A. Mykyrtychan, R.A. Mishagin \\ TO THE QUESTION OF THE IMPROVEMENT OF THE ORGANIZATION OF CARGO DELIVERY OF AGRICULTURAL PRODUCTION (ON THE EXAMPLE OF THE ENTEPPRISES WITH- IN THE ASSOCIATION "PF\&AIE OF SIBERIA"}

Вопрос повышения эффективности функционирования сельскохозяйственных предприятий является одной из стратегических задач развития экономики Российской Федерации ввиду заявленного курса на импортозамещение продуктов питания. В настоящее время немалая доля продуктов питания в страну импортируется из зарубежных стран по причине более низких издержек на производство сельскохозяйственной продукции в странах Азии. Следствием данной ситуации становится снижение уровня развития сельских территорий страны и рост зависимости внутреннего рынка продовольственных товаров от внешнеэкономической конъюнктуры. В наибольшей степени данная проблема проявляется в регионах Сибирского и Дальневосточного федеральных округов, где менее благоприятные в сравнении с европейской частью России природно-климатические условия в значительной степени усугубляются недостаточным уровнем развития объектов логистической инфраструктуры, включая как дорожно-транспортную сеть, так и объекты грузопереработки и логистического сервиса. Как следствие - доступ продукции местных сельхозтоваропроизводителей на рынок оказывается ограниченным. Одной из наиболее проблемных отраслей сельского хозяйства регионов Енисейской Сибири является производство мяса и мясных продуктов, где доля импорта в общем объеме потребления является наибольшей. Во многом данная проблема вызвана высокими издержками на доставку продукции местных предприятий к пунктам переработки и крупнейшим региональным рынкам сбыта. Решением данной проблемы может стать консолидация отправок грузов сельхозтоваропроизводителей, позволяющая минимизировать транспортные издержки за счет эффекта масштаба. В данном исследовании на примере компаний-производителей мясной продукции, входящих в Ассоциацию «Крестьянско- 
фермерских хозяйств и агропромышленных предприятий Сибири», доказывается эффективность консолидации отправок грузов как способа совершенствования организации грузоперевозок в сельском хозяйстве. Оценивается экономическая эффективность предлагаемьх мер.

Ключевъе слова: логистика, региональная логистика, транспортная логистика, автомобильный транспорт, грузоперевозки, сельское хозяйство.

The question of increasing the efficiency of functioning of agricultural enterprises is one of strategic problems of the development of the economy of the Russian Federation in view of declared course on import substitution of nutrition products. Now considerable share of food is imported to the country from foreign countries because of lower costs for receiving agricultural production in the countries of Asia. The decrease in the level of the development of rural territories of the country and growth of the dependence of domestic market in foodstuff on external economic environment turns out to be the consequence of the situation. Most of the problem is shown in the regions of Siberian and Far East Federal districts where climatic conditions, less favorable in comparison with European part of Russia, are substantially aggravated with insufficient level of the development of the objects of logistic infrastructure, including both road and transport network, and objects of cargo handling and logistic service. As a result the access of production of local agricultural producers to the market is limited. One of the most controversial branch of agriculture of the regions of the Yenisei Siberia is meat and meat products making where import share in the total amount of consumption is the greatest. In many respects this problem is caused by high costs for the delivery of production of local enterprises to points of processing and the largest regional sales markets. The consolidation of sending freights of agricultural producers allowing minimizing transport costs at the expense of scale effect can become the solution of the problem. In the research on the example of manufacturing companies of meat production entering the Association "Country farms and agrarian and industrial enterprises of Siberia" the efficiency of consolidation of sending freights as the way of improvement of the organization of cargo transportation in agriculture was proved. Economic efficiency of proposed measures was estimated.

Keywords: logistics, regional logistics, transport logistics, motor transport, cargo transportation, agriculture.

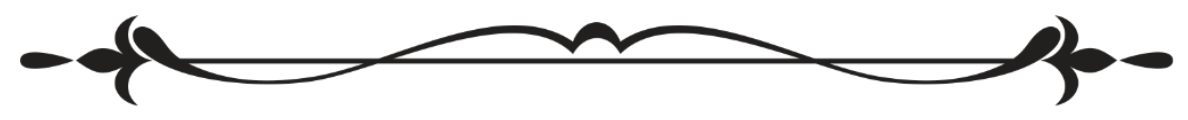

Грузоперевозки играют огромную роль в экономике большинства стран, в том числе и в Российской Федерации, где большая географическая отдаленность объектов экономики влечет за собой повышенные из- 


\section{Социально-экономический и әуманитарный журнал Красноярского ГАУ. 2019. № 4}

держки в цепях поставок. Исходя из результатов исследований, развитие и повышение эффективности грузоперевозок является неотъемлемым условием развития рыночной экономики, причем оправданным считается развитие транспортно-логистической инфраструктуры с учетом резервов дальнейшего экономического развития [7-9].

По состоянию на 2019 г. все большее значение в суммарном объеме грузоперевозок продукции сельскохозяйственных предприятий приобретает автомобильный транспорт. Основными причинами этого являются рост автомобилизации в стране и одновременное развитие малых предприятий, для которых использование иных видов транспорта является менее выгодным. В результате, на рынке автомобильных грузоперевозок присутствует конкуренция и расширяется спектр оказываемых услуг [1]. Таким образом, создаются условия для дальнейшего развития аутсорсинга на рынке транспортных услуг. Его можно рассматривать в качестве действенного способа повышения эффективности деятельности сельскохозяйственных предприятий, так как благодаря его внедрению появляется возможность снижения затрат на непрофильные виды деятельности, и соответственно - расширения бизнеса [2, с. 316].

Среди очевидных преимуществ использования аутсорсинга (снижение непрофильных расходов, ликвидация непрофильных видов деятельности [3, с. 156]), рассматривая возможности внедрения его на сельскохозяйственных предприятиях, стоит уделить особое внимание на возможность консолидации отправок при помощи крупнотоннажного транспорта. В настоящее время все большее значение приобретают малые (крестьянско-фермерские) хозяйства, не имеющие больших объемов производства, вынужденные тратить существенные средства на доставку готовой продукции на пункты переработки или рынки сбыта. Использование крупнотоннажного транспорта позволяет увезти больше продукции сразу от нескольких производителей, что позволяет сократить расходы на перевозку за счет эффекта масштаба при доставке консолидированных грузов. Консолидированным или сборным грузом называют различные партии товаров, объекты разного объема и размера, которые группируются для перевозки на одном транспортном средстве в целях экономии. Как правило, такие грузы принадлежат разным отправителям и предназначаются различным получателям [4]. Несмотря на очевидные преимущества данной схемы, многие малые предприятия попрежнему вынуждены использовать собственный транспорт [5, с. 89], снижая тем самым свою экономическую эффективность. Следовательно, оптимизация грузоперевозок является задачей, выходящей за рамки отдельных экономических субъектов и позволяющей говорить об актуальности их совершенствования посредством сторонних организаций.

Ассоциация «Крестьянско-фермерских хозяйств и агропромышленых комплексов (КФХ и АПК) Сибири» существует с 2016 г. и является социально ориентированной некоммерческой организацией. Она объе- 
диняет крупные и малые сельскохозяйственные предприятия Республики Хакасия различных форм собственности, оказывая им полный спектр услуг в области информационной логистики и продвижения товаров на рынки сбыта в республике и за ее пределами [6].

Рассмотрим пути оптимизации грузоперевозок на примере крестьянско-фермерских и агропромышленных предприятий, производящих мясную продукцию и входящих в КФХ и АПК Сибири. На настоящий момент именно данный сектор сельского хозяйства в Российской Федерации является наиболее зависимым от импорта, и, следовательно, в наибольшей степени нуждающимся в оптимизации транспортных издержек. Для того чтобы затраты на грузоперевозки уменьшились, организации, которые пользуются услугами транспортных компаний, могут поспособствовать появлению консолидированных перевозок. То есть отправлять свой груз в одной большой машине с грузом других организаций, которые находятся в том же районе.

Для того чтобы рассчитать консолидированные перевозки, рассчитаем оптимальные маршруты для каждого района, которые помогут понять, сколько пройдет километров машина и сколько нужно средств на грузоперевозку крупнотоннажным транспортом. Исходя из результатов исследований, проведенных специалистами кафедры «Логистика и маркетинг в АПК», средняя стоимость транспортных услуг в Красноярском крае и Республике Хакасия представлена данными, приведенными в таблице 1, по состоянию на конец 2018 г.

Таблица 1

Стоимостные показатели для разных видов транспорта

\begin{tabular}{|l|c|}
\hline \multicolumn{1}{|c|}{ Вид грузового транспорта } & $\begin{array}{c}\text { Себестоимость } \\
\text { перевозки, руб/1 ткм }\end{array}$ \\
\hline Мелкотоннажный автотранспорт & 33,65 \\
\hline Крупнотоннажный автотранспорт & 14,38 \\
\hline Еврофуры & 5 \\
\hline Железнодорожный транспорт & 11,48 \\
\hline Речной транспорт & 4,83 \\
\hline
\end{tabular}

В данной статье представлены результаты разработки оптимальных маршрутов по районам Республики Хакасия, построенных с целью максимального охвата сельскохозяйственных предприятий в рассматриваемом районе и, следовательно, снижения удельных логистических издержек на 1 ткм.

Маршрут консолидации отправок по Алтайскому району составляет 255 км в обе стороны (рис. 1). В районе имеется 15 фермерских хозяйств, отгружающих 179,9 т мясной продукции в год. Исходя из себестоимости 


\section{Социалъно-экономический и гуманитарный журнал Красноярского ГАУ. 2019. №4}

грузоперевозок крупнотоннажным транспортом, годовая себестоимость консолидированных отправок грузов составит 660042 руб. в год.

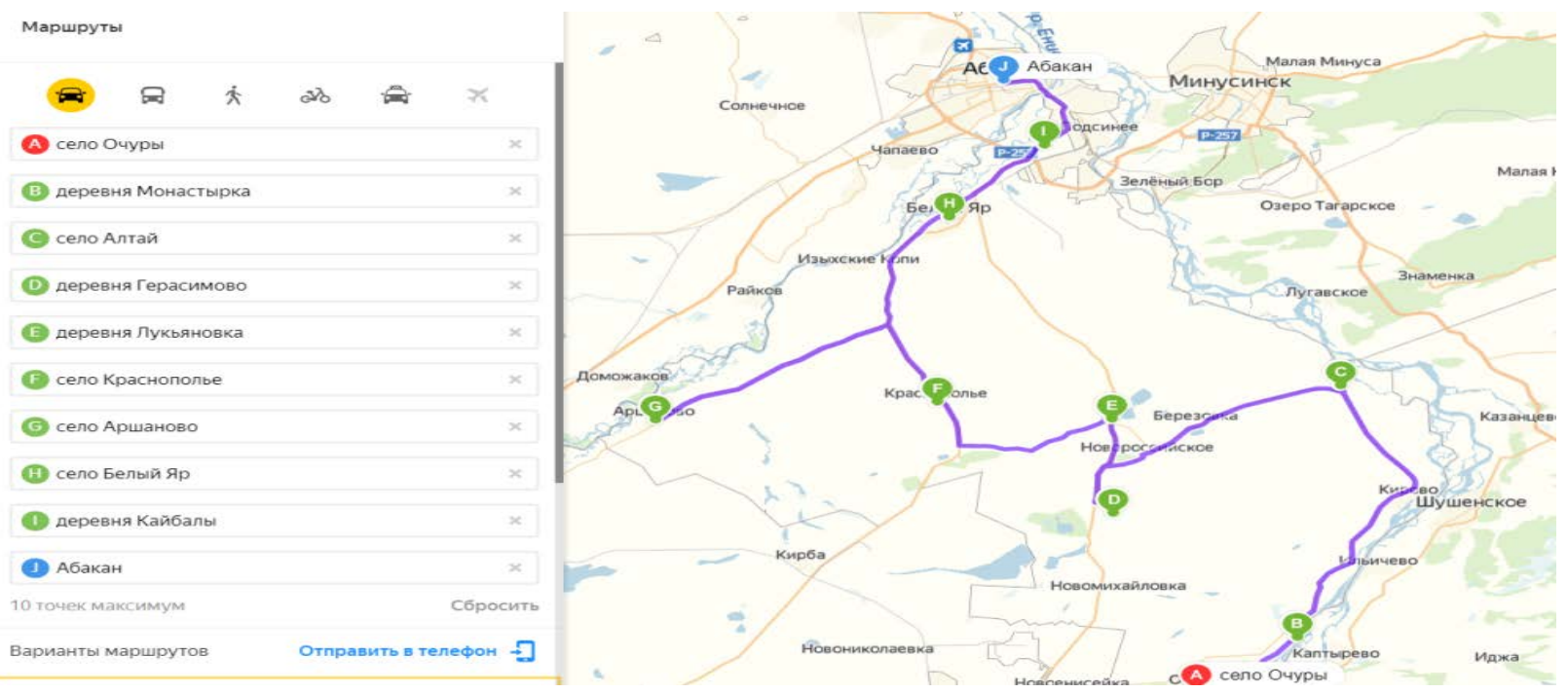

Рис. 1. Схема консолидации грузоотправителей в Алтайском районе Республики Хакасия

Маршрут консолидации отправок по Аскизскому району составил 390 км в обоих направлениях (рис. 2). В Аскизском районе имеется 34 фермерских хозяйства. В год все эти хозяйства отгружают 203,8 т мяса. Соответственно, годовая стоимость затрат на консолидированную отправку грузов в Аскизском районе составит 1144 072,8 руб.

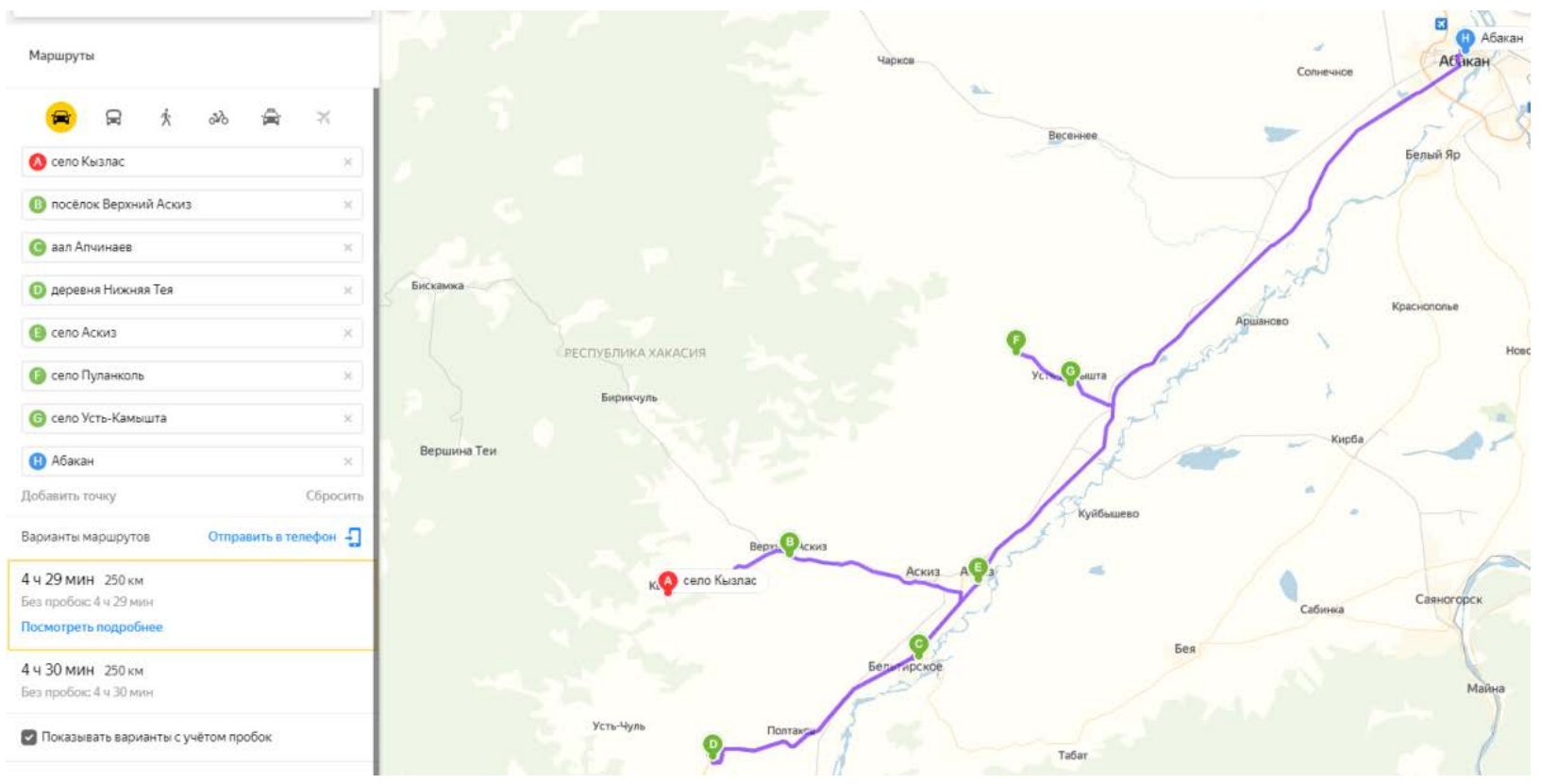

Рис. 2. Схема консолидации грузоотправителей в Аскизском районе Республики Хакасия 
Маршрут консолидации отправок в Бейском районе составил 410 км в обе стороны (рис. 3). В Бейском районе имеется 43 фермерских хозяйства. В год все эти хозяйства отгружают 216,5 т мяса. Соответственно, годовая стоимость затрат на консолидированные грузоперевозки мясной продукции в составит 1273 492,8 руб.

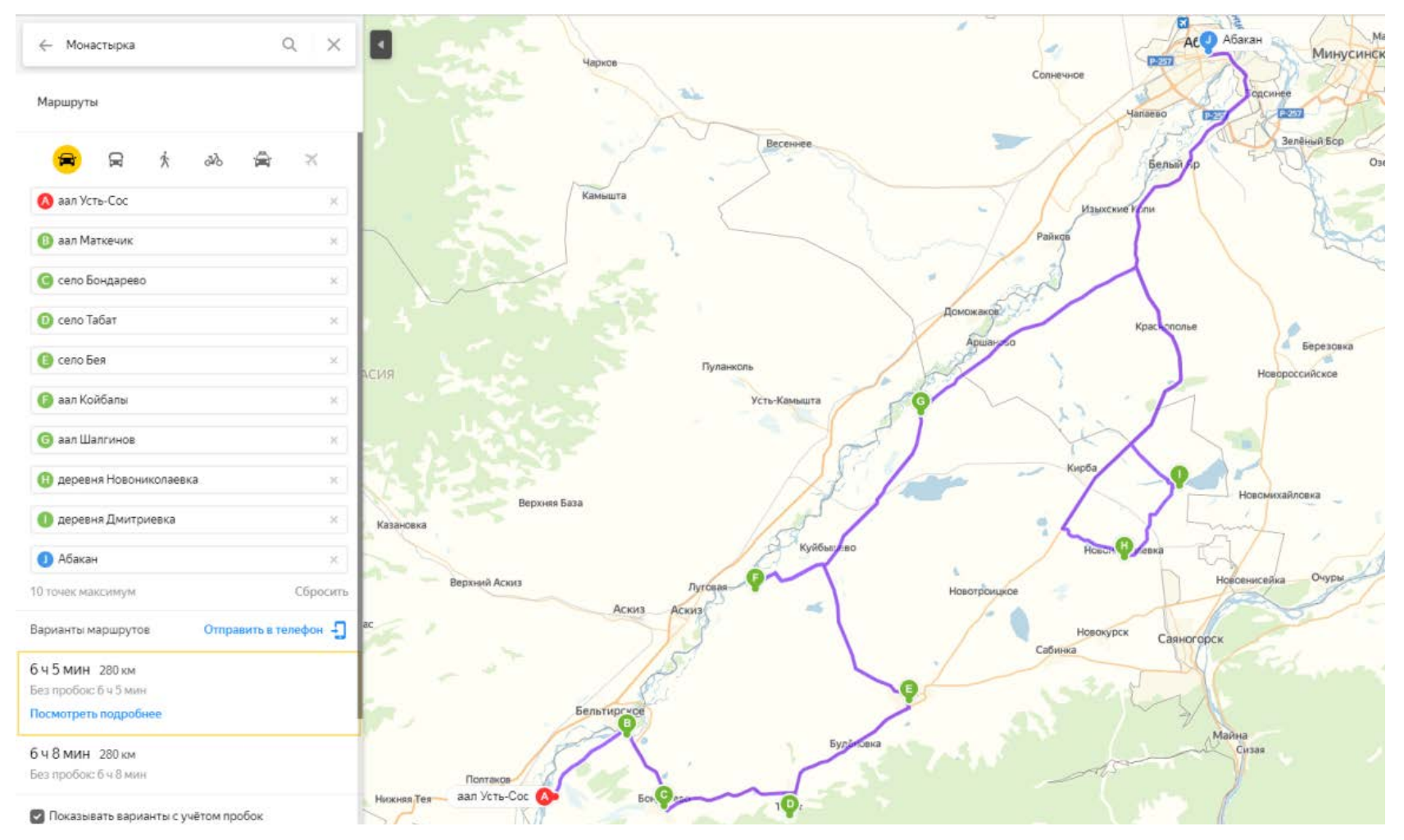

Рис. 3. Схема консолидации грузоотправителей в Бейском районе Республики Хакасия

Маршрут консолидации отправок по Боградскому району составил 390 км в обе стороны (рис. 4). В Боградском районе имеется 24 фермерских хозяйства с годовым грузооборотом в 196,9 т мясной продукции. Следовательно, величина затрат на грузоперевозку в Боградском районе будет составлять 1103 693,8 руб.

Маршрут консолидации отправок в Орджоникидзевском районе составит 540 км в обе стороны вследствие отдаленности данного района от регионального центра (рис. 5). В Орджоникидзевском районе имеется 5 фермерских хозяйств. В год все эти хозяйства отгружают 55,1 т мяса. Соответственно, величина затрат на грузоперевозку будет составлять 428639,0 руб. 


\section{Социалъно-экономический и гуманитарный журнал Красноярского ГАУ. 2019. №4}

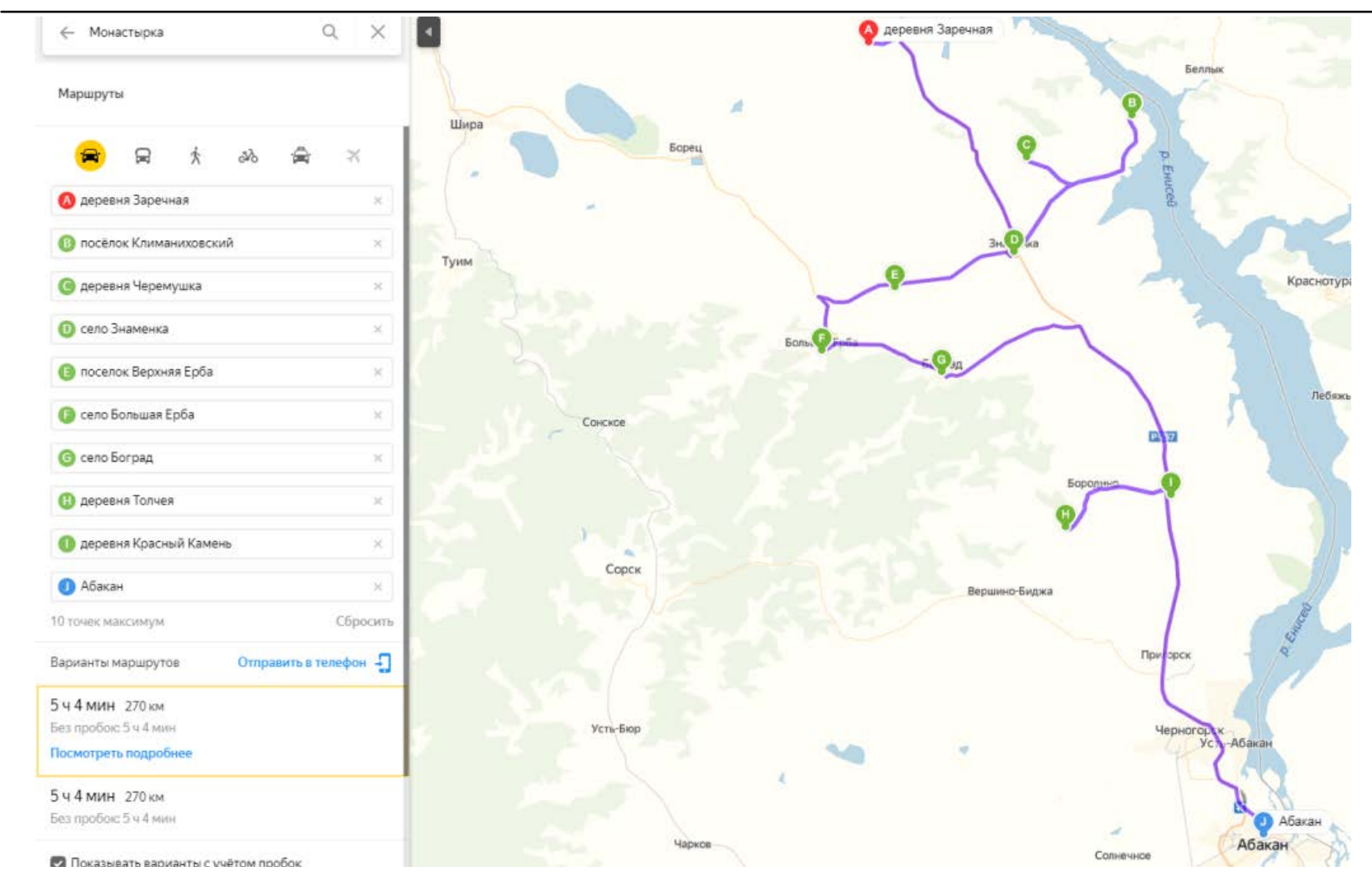

Рис. 4. Схема консолидации грузоотправителей в Боградском районе Республики Хакасия

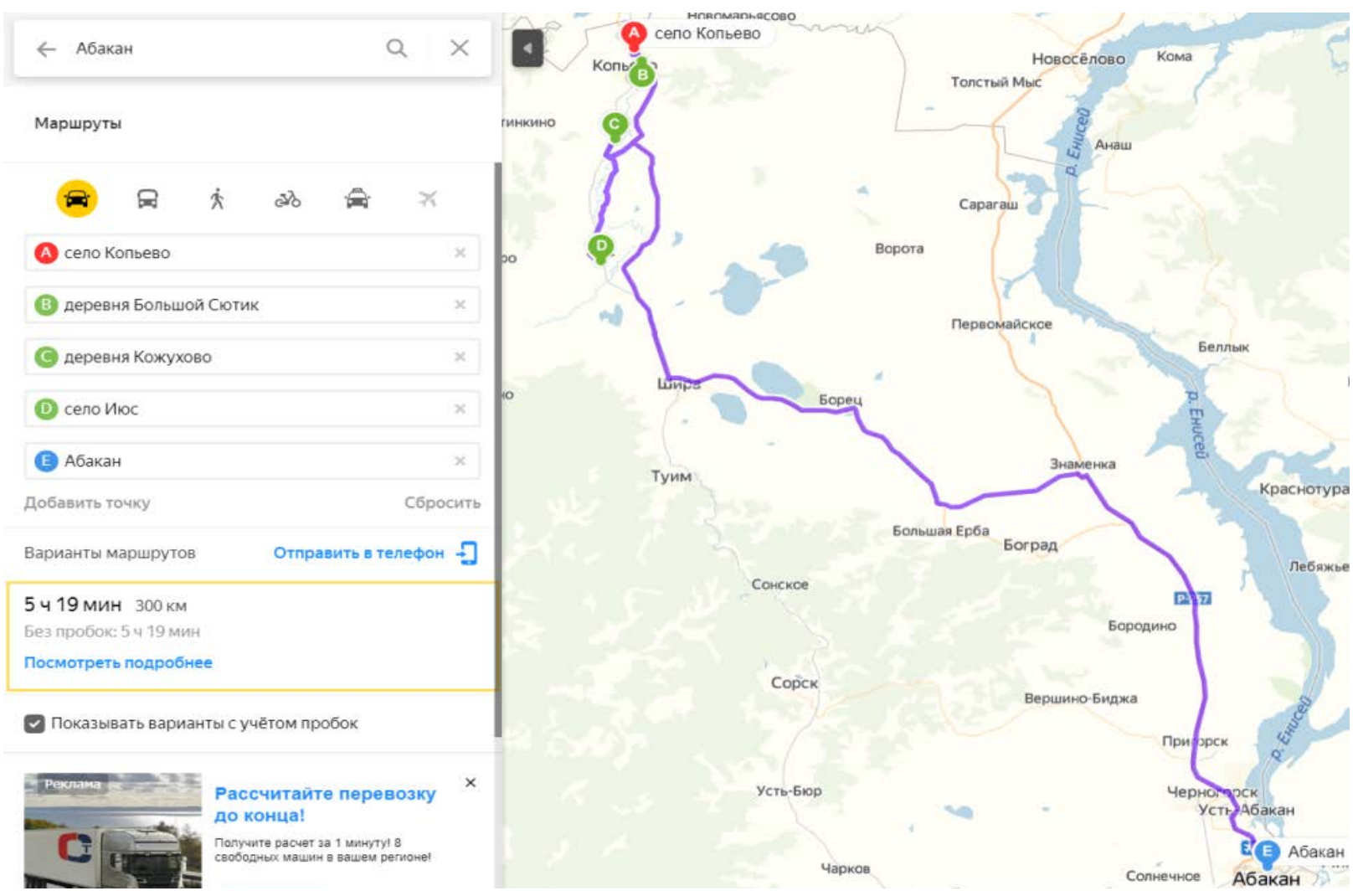

Рис. 5. Схема консолидации грузоотправителей в Орджоникидзевском районе Республики Хакасия 
Маршрут консолидации отправок по Таштыпскому району составил 390 км в обе стороны (рис. 6). В Таштыпском районе имеется 3 фермерских хозяйства, производящих 7,4 т мясной продукции в год. Соответственно, величина затрат на грузоперевозки будет составлять 40379,04 руб. в год.

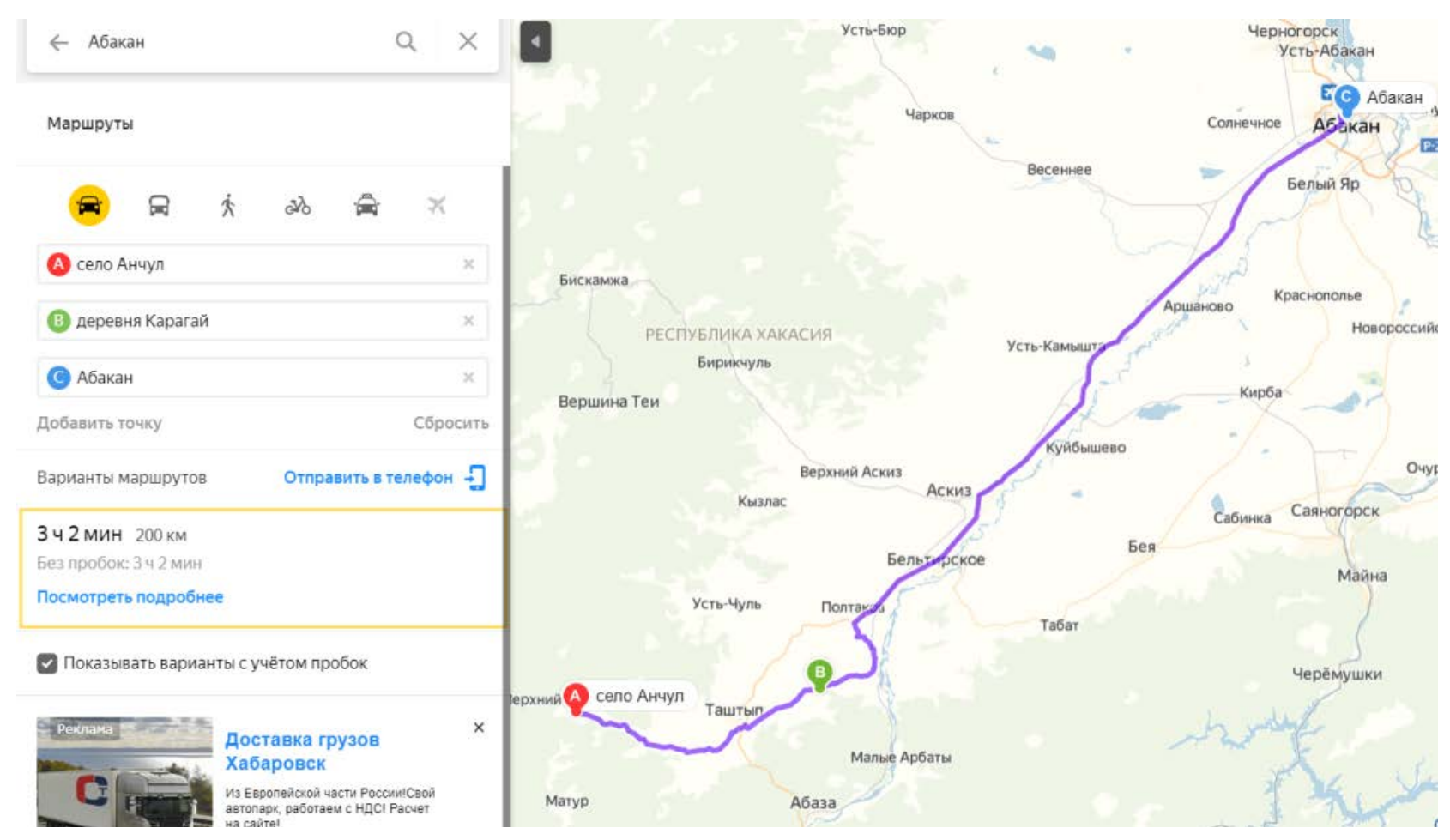

Рис. 6. Схема консолидации грузоотправителей

в Таштыпском районе Республики Хакасия

Маршрут консолидации отправок в Усть-Абаканском районе составил 355 км в обе стороны (рис. 7). В Усть-Абаканском районе имеется 59 фермерских хозяйств. В год все эти хозяйства отгружают 500,5 т мяса. Суммарная величина затрат на консолидированые грузоперевозки будет составлять 2554 492,о руб. в год.

Наконец, маршрут консолидации отправок Ширинского района составил 530 км в обе стороны (рис. 8). В Ширинском районе имеется 15 фермерских хозяйств. В год все эти хозяйства отгружают 30,4 т мяса. Годовая стоимость затрат на грузоперевозку будет составлять 228 642,o руб.

Таким образом, суммарные затраты на доставку мясной продукции от предприятий Республики Хакасия путем аутсорсинга и консолидации отправок составят 7433 453,4 руб. (37,6 тыс. руб. в расчете на 1 предприятие в год).

Для сравнения приведем стоимость затрат на грузоперевозки для компаний, которые используют собственный транспорт (данные компании для перевозки грузов используют автомобиль ГАЗель 3302) (табл. 2). 
Маршруты

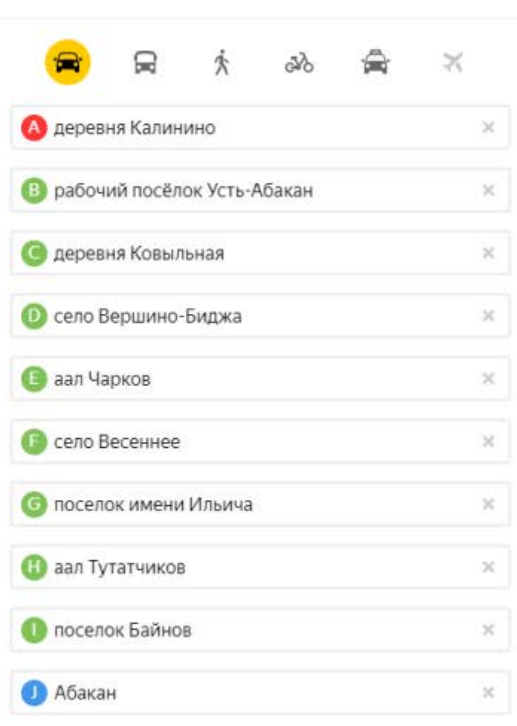

10 точек максимум

Варианты маршрутов

$4432 \mathrm{MUH} 260 \mathrm{kM}$

Отправить в телефон -7

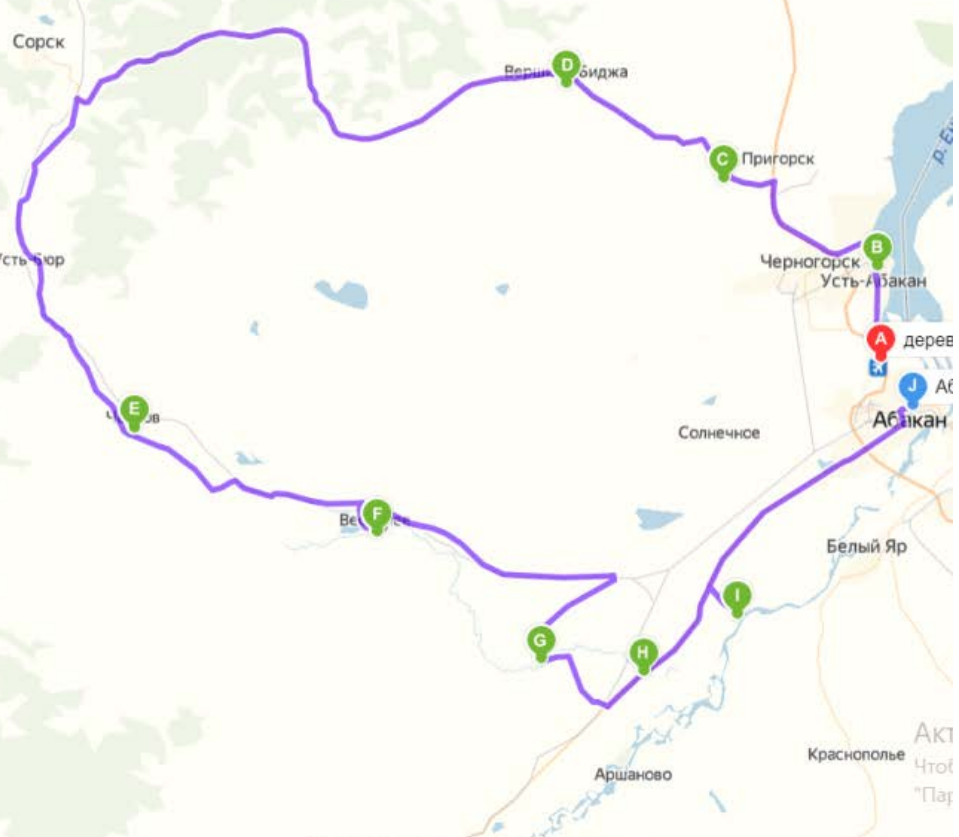

Рис. 7. Схема консолидации грузоотправителей в Усть-Абаканском районе Республики Хакасия

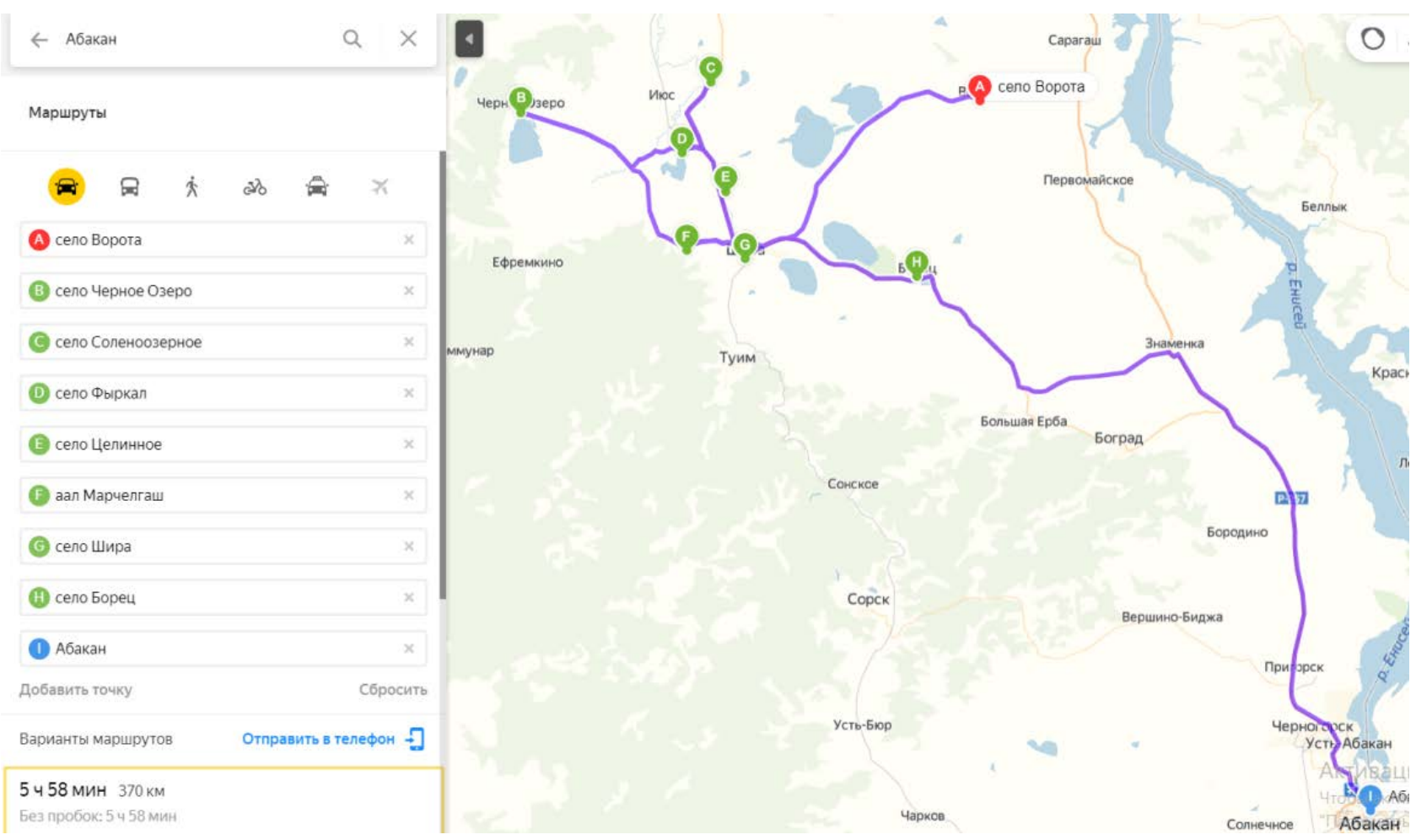

Рис. 8. Схема консолидации грузоотправителей в Ширинском районе Республики Хакасия 


\section{Сравнительные показатели затрат на аутсорсинг и собственный транспорт}

\begin{tabular}{|l|c|c|c|c|c|}
\hline \multicolumn{1}{|c|}{ Компании } & $\begin{array}{c}\text { Расстояние } \\
\text { до г. Абакана, } \\
\text { км }\end{array}$ & $\begin{array}{c}\text { Объем } \\
\text { за год, } \\
\text { тонн }\end{array}$ & $\begin{array}{c}\text { Затраты } \\
\text { на собственный } \\
\text { транспорт, } \\
\text { руб/год }\end{array}$ & $\begin{array}{c}\text { Аутсорсинг, } \\
\text { руб/год }\end{array}$ & $\begin{array}{c}\text { Откло- } \\
\text { нение,\% }\end{array}$ \\
\hline $\begin{array}{l}\text { ООО «Аскизский } \\
\text { племенной» }\end{array}$ & 69 & 3,7 & 456841,8 & 17181,69 & $-96,24$ \\
\hline $\begin{array}{l}\text { «Традиции и тех- } \\
\text { нологии» }\end{array}$ & 86 & 13,1 & 459069,4 & 75820,18 & $-83,48$ \\
\hline ООО «Июс-Агро» & 239 & 1,6 & 479118,6 & 25735,52 & $-94,63$ \\
\hline ООО «Бон» & 239 & 3,5 & 479118,6 & 56296,45 & $-88,25$ \\
\hline ООО «Мустанг» & 203 & 7,6 & 474401,1 & 103830,44 & $-78,11$ \\
\hline Итого & 836 & 29,5 & 2348549,4 & 278864,28 & $-88,13$ \\
\hline
\end{tabular}

Исходя из данных таблицы 2, можно сделать вывод о том, что затраты на собственный транспорт очень высоки по сравнению с затратами на аутсорсинг вследствие высоких затрат на содержание подвижного состава и нерегулярности перевозок готовой продукции в течение года. Следовательно, использование аутсорсинга и консолидации отправок позволит существенно сократить логистические издержки. В целом по рассмотренным в ходе исследования сельскохозяйственным предприятиям экономия затрат на доставку готовой продукции составит 88,1\%, что позволяет снизить суммарные транспортные издержки более чем на 30 \%, а общие издержки предприятий - на $2,8 \%$.

Таким образом, использование консолидации отправок готовой продукции является действенным способом повышения эффективности сельскохозяйственных предприятий, позволяющим увеличить конкурентоспособность их продукции в сравнении с зарубежными аналогами. Следовательно, реализация данных мер соответствует стратегическим задачам развития агропромышленного сектора Российской Федерации, позволяя снизить зависимость потребительского рынка страны от внешних факторов.

\section{Литература}

1. O компании: официальный сайт предприятия Delko. - URL: https:// del-ko.ru/about (дата обращения: 15.06.2018).

2. Харламова T.Н. Управление затратами на качество продукции. - М.: Изд-во ТГТУ, 2013. - 415 с. 


\section{Социально-экономический и әуманитарный журнал Красноярского ГАУ. 2019. № 4}

3. Трунина В. Ф. Преимущества и недостатки бухгалтерского аутсорсинга в России. - М.: Изд-во Михайлова, 2013. - 277 с.

4. Чепурной М.Ю. Специфика сборных грузов и способы оптимизации их доставки (международные перевозки) // Логистика сегодня. 2007. - № 6. - 456 c.

5. Земскова O.M., Щепотько М.М. Логистика в России и за рубежом: сравнительный анализ // Экономика и современный менеджмент: теория и практика. - 2015. - № 56. - С. 195- 200.

6. Об Ассоциации: официальный сайт Ассоциации «КФХ и АПК». URL: http://akfhsibiri.ru (дата обращения: 16.o6.2018).

7. Алесинская T.B. Основы логистики. Функциональные области логистического управления. Ч. 3. - Таганрог: Изд-во ТТИ ЮФУ, 2010. $116 \mathrm{c}$.

8. Вельможин А.В., Гудков В.А., Миротин Л.Б., Куликов А.В. Грузовые автомобильные перевозки: учеб. для вузов. - М., 2006. - 560 с.

9. Никифоров В.В. Логистика. Транспорт и склад в цепи поставок. - М.: ГроссМедиа, 2008. - 149 с.

\section{Literatura}

1. O kompanii: oficial'nyj sajt predprijatija Delko. - URL: https://delko.ru/about (data obrashhenija: 15.06.2018).

2. Harlamova T.N. Upravlenie zatratami na kachestvo produkcii. - M.: Izd-vo TGTU, 2013. - $415 \mathrm{~s}$.

3. Trunina V. F. Preimushhestva i nedostatki buhgalterskogo autsorsinga v Rossii. - M.: Izd-vo Mihajlova, 2013. - 277s.

4. Chepurnoj M.Ju. Specifika sbornyh gruzov i sposoby optimizacii ih dostavki (mezhdunarodnye perevozki) // Logistika segodnja. - 2007. № $6 .-456 \mathrm{~s}$.

5. Zemskova O.M., Shhepot'ko M.M. Logistika v Rossii i za rubezhom: sravnitel'nyj analiz // Jekonomika i sovremennyj menedzhment: teorija i praktika.- 2015. - № 56. - S. 195- 200

6. Ob Associacii: oficial'nyj sajt Associacii «KFH i APK». - URL: http:// akfhsibiri.ru (data obrashhenija: 16.06.2018).

7. Alesinskaja T.V. Osnovy logistiki. Funkcional'nye oblasti logisticheskogo upravlenija. Ch. 3. - Taganrog: Izd-vo TTI J uFU, 2010. - 116 s.

8. Vel'mozhin A.V., Gudkov V.A., Mirotin L.B., Kulikov A.V. Gruzovye avtomobil'nye perevozki: ucheb. dlja vuzov. - M., 2006. - 560 s.

9. Nikiforov V.V. Logistika. Transport i sklad v cepi postavok. - M.: GrossMedia, 2008. - 149 s.

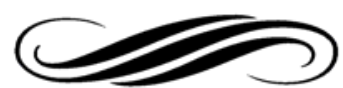

